\title{
Space use of wild boar (Sus Scrofa) in Budapest: are they resident or transient city dwellers?
}

\author{
A. Csókás ${ }^{1} \cdot$ G. Schally ${ }^{1}$ L. Szabó ${ }^{1} \cdot$ S. Csányi ${ }^{1} \cdot$ F. Kovács $^{2} \cdot$ M. Heltai $^{1}$
}

Received: 17 September 2019 / Accepted: 31 March 2020 / Published online: 16 April 2020

(c) The Author(s) 2020

\begin{abstract}
In our study, we examined the movement of two wild boars marked with GPS/GSM transmitters in city of Budapest. We hypothesised that: the wild boars do not leave the urban area (H1); the wild boars prefer places that are less disturbed by people, and which are rich in potential hiding places (H2); and their home ranges would be smaller than that of wild boars living in non-urban environment (H3). Based on our results, we accepted our first hypothesis, as the wild boars had not left the area of Budapest. However, we partly rejected our second hypothesis: the wild boars preferred urban areas that were forested and richly covered with vegetation; however, human presence therefore disturbance was also high in those areas. The home range sizes of both marked wild boar sows were remarkably smaller than those of the wild boars living in natural environment (H3). City habitat modification, e.g. clearing undergrowth vegetation, could result that wild boars cannot find any hiding places. The significant part of food sources will disappear with the elimination of these places. By eliminating the two main factors together could prevent wild boars finding their living conditions within the city.
\end{abstract}

Keywords Urbanisation $\cdot$ Sus scrofa $\cdot$ Home range $\cdot$ Urban wildlife $\cdot$ Budapest

\section{Introduction}

Due to the constant expansion of urban areas, natural habitat for wildlife is rapidly decreasing. The appearance of generalist and highly adaptive species in the cities is one characteristic of this tendency (Møller 2009). After their appearance, some of these species eventually settle down and the city becomes their habitat. The biggest problem in Europe is caused by foxes (Vulpes vulpes) (Hegglin et al. 2004), badgers (Meles meles) (Harris 1984) and, most recently, wild boars (Cahill et al. 2003; Cahill and Llimona 2004; Kotulski and König 2008; Hamrick et al. 2011; Cahill et al. 2012; Bogdán and Heltai 2014) in the city. This phenomenon, however, cannot be explained exclusively by the expansion of urban areas. As special habitats, cities can provide

A. Csókás

csokas.adrienn@gmail.com

1 Present Address: Institute for Wildlife Conservation, Szent István University, Gödöllő, Páter Károly utca 1., 2100, Hungary

2 Department of Wildlife Management, Ministry of Agriculture, Budapest, Kossuth Lajos tér 11, 1055, Hungary not only suitable hiding places, but also occasional feeding and breeding grounds for a number of species (Heltai and Szőcs 2008). Human settlements may offer a wider range of food resources and more favourable climatic conditions than the surrounding natural environment at certain times, which can result in prolonged reproduction period. This helps the survival of urban species (Møller et al. 2012), with the potential of having more offsprings.

As far as habitat preferences are concerned, the wild boar is truly a generalist species (Taylor 1999; West et al. 2009; Cuevas et al. 2010; Thurfjell et al. 2015), and it occurs in very different types of habitats (McGaw and Mitchell 1998; Taylor1999; Cuevas et al. 2010; Massei et al. 2011; Hamrick et al. 2011). In the recent decades, it has appeared in the outskirts of cities (e.g. Berlin, Barcelona, Genoa) (McGaw and Mitchell 1998; Taylor 1999; Cuevas et al. 2010; Massei et al. 2011; Hamrick et al. 2011), which indicates the expansion of its range. This process was related to the overpopulation of this game in the wild and its high adaptability to different circumstances.

Wild boars are capable of adapting and reacting to altering circumstances (Taylor1999; Keuling et al. 2008a). Their occurrence is predominantly determined by the availability of food resources and hiding places (Abaigar et al. 1994; 
Acevedo et al. 2006). The denser the vegetation (particularly if it provides food as well as shelter), the more likely they prefer that habitat. Although the wild boar can consume a wide range of food resources, food is still one of the limiting factors in its habitat use (Taylor 1999). Keuling et al. (2008b) found correlation between habitat type and season, as available shelter, food and other resources showed a seasonal variation in different habitat types. Available food resources may even result in differences in habitat use (Keuling et al. 2008a).

The primary reason for the appearance and presence of wild boar in the urban area is the constant availability of food (Cahill et al. 2012; Licoppe et al. 2013). Nutrition is important because it provides better condition, higher reproduction and higher survival rates (Prange et al. 2003; Gehrt, 2007). Although the quality of the food in the city is often worse than that of the natural environment, it is much more abundant and actually available throughout the year (Creacy 2006). Although wild boar is omnivorous, the results of nutritional studies show that it consumes mainly plants (Taylor 1999; Heltai et al. 2016). Usually, they consume the largest amount of food available and the easiest to obtain (Calegne et al. 2004).

In our previous studies, we examined the feeding behaviour of wild boars in urban area. The results showed that they are searching for natural feed per se; however, the primary food source was proven to be different from those found in natural habitat (Heltai et al. 2016; Katona et al. 2018a, b). In the forest patches of 12th district of Budapest, the proportion of the oaks were high. The most preferred basic food source for wild boars is the oak acorns (Katona and Heltai 2018). Another important factor is the low or even complete lack of predators (Licoppe et al. 2013). In addition, hunting within inhabited areas is severely restricted or, in many cases, completely prohibited, so that hunting pressure is extremely reduced or even eliminated (Licoppe et al. 2013; Brash et al. 2004; Creacy 2006; Badry and Hesse 2010; Weckel and Rockwell 2013).

In Hungary, according to the legal regulations, areas of the cities are not part of hunting grounds. Hunting is forbidden in the populated area (in the cities), and hunting is possible only with special permission from the police. In the absence of hunting, wild boars are constantly presence in urban areas and the damage caused by them has now become permanent (Bogdán and Heltai 2014). In an urban area, food, water and shelter for wild boars (and other species) are also available when conditions change outside of urban areas (e.g. due to winter, drought or even hunting). As a result, urban areas can be much more attractive even when the wild boar population density in these areas is high (Licoppe et al. 2013).

One of the problems with urban presence of wild animals is that some species, such as wild boar, can cause damage.
This determines that people how accept the presence of that species. Bogdán and Heltai (2014) examined 47 reports what send to the Budapest Forestry Company. Most of the reports stated that residents fear, feel threatened and fear children due to wild boars. Damages are as follows: damage to the fence (49\%), rooting damage (45\%), burgling and breaking in the garden (19\%), destruction of the vegetable garden and cultivated areas (21\%). Damage and burying of the lawn were reported in $8.5 \%$. Conflicts between wild boars and dogs, damage to garden equipment and structures (damaging the garden pond, irrigation system, destroying garden items, smashing patios and endangering ground cables) are also common.

From the above, we could mistakenly conclude that a species appearing in a city is less stressed. However, this is not the case. Although some sources of stress disappear, newer ones appear. These new sources of stress can change the behaviour and lifestyle of animals in order to remain successful in the city. This change can also occur in nutrition, reproduction, distribution, activity and survival (Ditchkoff et al. 2006). Since human activity is most present during the day, the activity period in the urban species is shifted to dusk or dawn, or in some cases strictly to the night (Ditchkoff et al. 2006).

In view of the above in our study, we examined the movement of two wild boar sows marked with GPS/GSM transmitters within the boundaries of Budapest. We had the following hypotheses:

H1 The sows live in the sampling area will not leave the municipal boundaries of Budapest.

H2 The sows predominantly prefer parts of the suburbs or outside of the city which are less disturbed by humans and which are rich in potential hiding places.

H3 The home ranges of the marked sows will be smaller than those of the wild boars living in their natural habitat.

\section{Materials and method}

\section{Study area}

The study area-except for 10 localisation points-was the 12th district of Budapest (47.50000 N, 19.00000 E). Out of the 10 points mentioned above, 9 are located in the area of Budaörs and one within the boundaries of the 2nd district. According to the Hungarian Central Statistical Office, the 12th district covers an area of 2667 ha (total area of Budapest is $52,514 \mathrm{ha}$ ), and its population in 2018 was 57,566 (the total population of Budapest is 1,752,286). The district is predominantly located in a mountainous region, and a 
significant part of it is covered by forests. $53.60 \%$ of the 2667 ha is purely urban area ( $1429.56 \mathrm{ha}$ ), while $42.75 \%$ is forest (1140 ha), i.e. outside areas. Within the district, the total of 97.44 ha is classified as forest but located inside the city (3.65\%) (https://www.ksh.hu/).

Within the study area are Normafa and the János Hill, which is a continuous forest area and other smaller forest patches. The most important plant communities in these areas are the Turkey oak (Quercus cerris)-sessile oak (Quercus petraea), sessile oak-hornbeam (Carpinus betulus) and beech (Fagus sylvatica) forests (Sütô et al. 2020).

Bogdán and Heltai (2014) examined the habitats preferred by wild boar in Buda (their study area is partly overlapping with the 12th district of Budapest). These habitats in order of frequency are: forest habitat (35.7\%), abandoned but fenced gardens $(28.6 \%)$, neglected plots and wooded area (10.7\%), public space (7\%). They are the least likely to return to wellkept gardens (3.6\%). With the exception of public spaces and well-kept gardens, the existence of hiding places was one of the most important factors for the appearance and settlement of wild boar in city.

\section{Marking of wild boar sows and data collection}

The marking of the sows with GPS/GSM transmitters was carried out with the cooperation of Pilis Park Forestry Company (Pilisi Parkerdő Zrt.) and the Institute for Wildlife Conservation of Szent István University, Gödöllő. The GPS PRO Light-1 Collar (VECTRONIC Aerospace GmbH, Berlin) type GPS-GSM radio-telemetry collars were placed on the animals, following anaesthesia, at the site of the Budapest Forestry of Pilis Park Forestry Company. The collars recorded data four times a day (at 4:00 a.m., 2:00 p.m., 7:00 p.m. and 10:00 p.m.).

Data for sow 1 were available from 19 September 2014 to 1 January 2016. As for sow2, the GPS transmitter recorded data between 8 January 2018 and 29 September 2018. In the case of sow1, it recorded the total of 1263 localisation points during 430 days, while for sow 2 the number of localisation points was 948 during 265 days (Fig. 1).

Whereas the sow 2 could only be examined for 265 days for sow1, we selected the GPS coordinates that contain the same period as sow2. Therefore, for sow1 we examined the period from 8 January 2015 to 29 September 2015. In this case, we were able to examine 265 days of data and 830 localisation points for sow 1 (sow $1_{\mathrm{sh}}$ ), where sow $1_{\mathrm{sh}}$ means shorter period ( 265 days out of 430 days) of first wild boar's examination period.

We examined the size of the sows' home ranges and analysed the data for the entire study period and within seasons. For clarification, we used the following terms to make a distinction between the different types of habitats within our study area:
Downtown areas inside the inhabited parts of 12th district of Budapest (with forest patches) (we marked this area with red colour on the map);

Suburbs areas within the municipal boundaries of 12th district of Budapest but outside the inhabited parts (we marked this area with green colour on the map except in the downtown located forest patches);

Populated area inhabited parts of 12th district of Budapest except in the downtown located forest patches (we marked this area with red colour on the map except in the downtown located forest patches);

Forested area forest patches within the municipal boundaries of 12th district of Budapest (we marked this area with green colour on the map).

For the seasons, we applied the following division: autumn (September 1-November 30); winter (December 1-February 28); spring (March 1-May 31), summer (June 1-August 31).

\section{Data assessment}

The localisation points were examined both cumulatively (total) and by season. Because we only have data from two sows, we were primarily able to perform descriptive analysis. As a result, for sow1, we merged data of the autumn months of 2014 and 2015 where it was possible. In the case of sow2, the autumn season could not be taken into account, as there was only 29 active days, and neither was the winter season complete with only 52 days. The movement of the marked sows was analysed by ESRI ArcMap (v10.2.2) geospatial software according to the proportion of the points recorded inside or outside the city, and in forested or urban areas.

Four hundred and six localisation points in autumn, 308 points in winter, 244 points in summer and 305 points in spring were recorded for sow1. For sow2, 115 localisation points in autumn, 162 points in winter, 342 points in summer and 329 points in spring were recorded. And finally, for sow $1_{\mathrm{sh}} 100$ localisation points in autumn, 181 points in winter, 244 points in summer and 305 points in spring were recorded.

Two methods were used to calculate the home range sizes. One of these is the most commonly used method, the minimum convex polygon (MCP) (Mohr 1947), and the other is the kernel home range (KHR) estimation (Worton1989). Parts of the calculations were performed with the ESRI software.

Home ranges were examined both on a total and on a seasonal basis. Areas calculated by MCP and KHR were displayed on a digital land cover map.

It is important to note that MCP overestimates the size of home ranges. The minimum convex polygon method provides a polygon in which no internal angle exceeds $180^{\circ}$. 


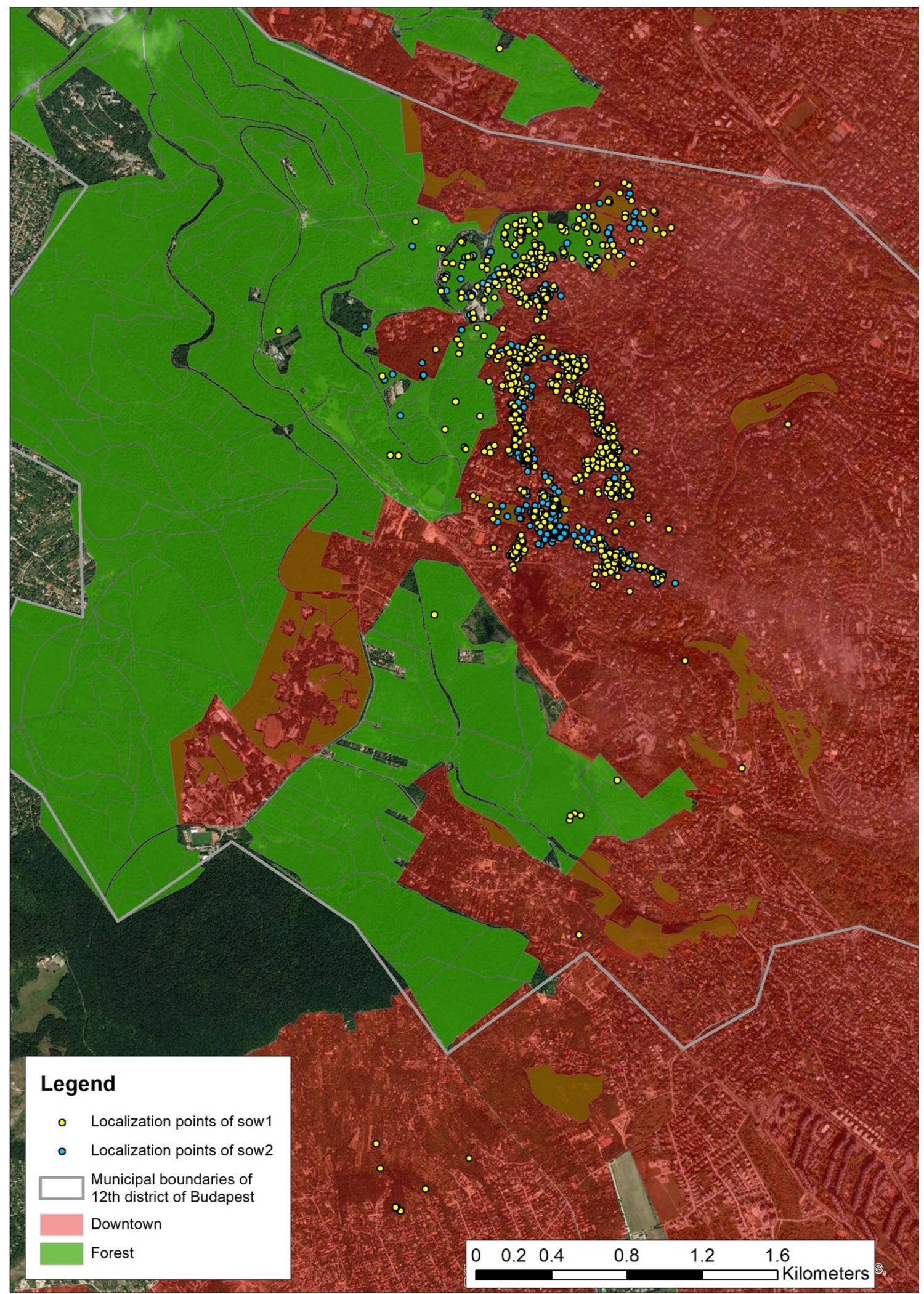

Fig. 1 Localisation points of sow1 and sow2 
The name of the method results from the fact that this polygon gives the smallest convex area that contains each and every localisation point. The error (overestimation) of MCP stems from the fact that that this polygon inevitably includes areas in which the animal has never been, or in many cases could not even reach (e.g. due to geographical factors) (Worton 1989).

The Kernel method is far more suitable for defining home range sizes. The kernel home range method uses isopleth lines, or we might as well call them density lines, to demonstrate the intensity of land use. Each isopleth is associated with a specific percentage (which in our case was $60 \%$ and $90 \%$ ), which refers to the percentage of the measured localisation points within the given area. It means that within the contours of an isopleths, the occurrence of the individual is invariable (Gemson et al. 2005).

\section{Results}

\section{Distribution of total and seasonal localisation points}

The majority of localisation points for both sows and in all three classes (total examination periods of sow1 and sow2, and shorter period of sow1) were recorded in the inner areas of the city both at total and seasonal levels (Table 1). In the case of sow1, there were 1069 points $(84.46 \%)$, whereas in the case of the second animal 883 points $(93.14 \%)$ and sow $1_{\mathrm{sh}} 720$ points $(86.75 \%)$ which were recorded inside the city. As for the seasons, the sows spent the most time (proportionally) in the inner areas during the summer. The occurrence of sow 1 inside the city was the lowest in autumn (321/406 localisation points-79.06\%), whereas for sow 2 and sow $1_{\text {sh }}$ it was the lowest in winter $(116 / 162$ points-71.60\%, respectively, 130/181 points-71.82\%).

A slightly more different, but similar result was obtained when we examined the distribution of localisation points for forested and urban areas (Table 2). The majority of the points were recorded in the urban areas. On a total basis (as a result of the three classes of data), $76.80 \%$ (970), $86.81 \%$ (823) and $78.67 \%$ (653) of the localisation points were registered in urban areas, respectively, while only $23.20 \%$ (293), $13.19 \%$ (125) and $21.33 \%$ (177) in the forested ones. As for the seasons, the distribution of points shows a similar pattern as well. The sows spent the most time in the urban areas during the summer, just like in the case of the inner city areas. $91.15 \%$ (sow 1 and sow $1_{\text {sh }}$ ) and $92.10 \%$ of the localisation points were recorded in urban areas. Similarly, their occurrence in the urban areas was the lowest during the autumn and the winter.

\section{Seasonal and total MCP sizes}

The total MCP size was 1040 ha in the case of sow1. A few extreme localisation points in early November increased the home range area to a great extent (Fig. 2). Among the seasonal MCP sizes, the largest one (729 ha) was calculated for the autumn of 2014, also due to the extreme points (Table 3). The smallest one was the MCP of the summer of 2015 with only 148 ha, which is just slightly smaller than the MCP of the spring in the same year (162 ha).

The size of sow2's total MCP was 244 ha, which is about quarter the size as that of the first sow's. The largest seasonal MCP was observed in spring with the size of 227 ha (Table 4). The smallest one was only 35 ha, detected in summer. The total MCP size was 256 ha in the case of sow $1_{\mathrm{sh}}$. This is similar in size to total MCP of sow2. The largest MCP (162 ha) was calculated for the spring (Table 5).

Table 1 Total and seasonal number and percentage of localisation points in downtown and suburbs

\begin{tabular}{|c|c|c|c|c|c|c|c|c|c|c|}
\hline & \multicolumn{2}{|l|}{ Autumn } & \multicolumn{2}{|l|}{ Winter } & \multicolumn{2}{|l|}{ Spring } & \multicolumn{2}{|l|}{ Summer } & \multicolumn{2}{|l|}{ Total } \\
\hline & Points (nr) & Points (\%) & Points (nr) & Points (\%) & Points (nr) & Points (\%) & Points (nr) & Points (\%) & Points (nr) & Points (\%) \\
\hline \multicolumn{11}{|l|}{ sow1 } \\
\hline Suburbs & 85 & 20.94 & 58 & 18.83 & 44 & 18.03 & 7 & 2.30 & 194 & 15.36 \\
\hline Downtown & 321 & 79.06 & 250 & 81.17 & 200 & 81.97 & 298 & 97.70 & 1069 & 84.64 \\
\hline Total & 406 & 100 & 308 & 100 & 244 & 100 & 305 & 100 & 1263 & 100 \\
\hline \multicolumn{11}{|c|}{ sow1 (shorter time) } \\
\hline Suburbs & 8 & 8 & 51 & 28.18 & 44 & 18.03 & 7 & 2.30 & 110 & 13.25 \\
\hline Downtown & 92 & 92 & 130 & 71.82 & 200 & 81.97 & 298 & 97.70 & 720 & 86.75 \\
\hline Total & 100 & 100 & 181 & 100 & 244 & 100 & 305 & 100 & 830 & 100 \\
\hline \multicolumn{11}{|l|}{ sow2 } \\
\hline Suburbs & 0 & 0 & 46 & 28.40 & 19 & 5.56 & 0 & 0 & 65 & 6.86 \\
\hline Downtown & 115 & 100 & 116 & 71.60 & 323 & 94.44 & 329 & 100 & 883 & 93.14 \\
\hline Total & 115 & 100 & 162 & 100 & 342 & 100 & 329 & 100 & 948 & 100 \\
\hline
\end{tabular}


Table 2 Total and seasonal number and percentage of localisation points in forested and urban areas

\begin{tabular}{|c|c|c|c|c|c|c|c|c|c|c|}
\hline & \multicolumn{2}{|l|}{ Autumn } & \multicolumn{2}{|l|}{ Winter } & \multicolumn{2}{|l|}{ Spring } & \multicolumn{2}{|l|}{ Summer } & \multicolumn{2}{|l|}{ Total } \\
\hline & Points (nr) & Points (\%) & Points (nr) & Points (\%) & Points (nr) & Points (\%) & Points (nr) & Points (\%) & Points (nr) & Points (\%) \\
\hline \multicolumn{11}{|l|}{ sow1 } \\
\hline Forested & 117 & 28.82 & 82 & 26.62 & 67 & 27.46 & 27 & 8.85 & 293 & 23.20 \\
\hline Urban & 289 & 71.18 & 226 & 73.38 & 177 & 72.54 & 278 & 91.15 & 970 & 76.80 \\
\hline Total & 406 & 100 & 308 & 100 & 244 & 100 & 305 & 100 & 1263 & 100 \\
\hline \multicolumn{11}{|c|}{ sow1 (shorter time) } \\
\hline Forested & 17 & 17 & 63 & 34.81 & 67 & 27.46 & 27 & 8.85 & 177 & 21.33 \\
\hline Urban & 83 & 83 & 118 & 65.19 & 177 & 72.54 & 278 & 91.15 & 653 & 78.67 \\
\hline Total & 100 & 100 & 181 & 100 & 244 & 100 & 305 & 100 & 830 & 100 \\
\hline \multicolumn{11}{|l|}{ sow2 } \\
\hline Forested & 3 & 2.61 & 62 & 38.27 & 34 & 9.94 & 26 & 7.90 & 125 & 13.19 \\
\hline Urban & 112 & 97.39 & 100 & 61.73 & 308 & 90.06 & 303 & 92.10 & 823 & 86.81 \\
\hline Total & 114 & 100 & 162 & 100 & 342 & 100 & 329 & 100 & 948 & 100 \\
\hline
\end{tabular}

The smallest one was the MCP of the autumn of with only $147 \mathrm{ha}$, which is similar to the MCP of the summer (148 ha). The seasonal home ranges are similar in size with little deviation between them.

When comparing the MCP sizes of the two sows, large deviation could be observed, as the only matching results were gained for the winter of sow 1 and the spring of sow2 MCP sizes, which were similar in size. Comparing the MCP sizes of sow $1_{\text {sh }}$ and sow2, it could be observed the winter and total MCP are similar in size. Little deviation is between in spring, and large deviation was calculated in autumn and summer.

\section{Seasonal and total KHR sizes}

The size of sow 1's total $90 \%$ KHR was 37.20 ha (Table 3) (Fig. 3). The summer home range size is relatively close to this with $29.22 \mathrm{ha}$. The one in spring was $20.32 \mathrm{ha}$. The largest home range sizes were detected in autumn and winter of 2014 , with very similar results. The $90 \%$ KHR in autumn of 2014 was 70.65 ha, while in winter of the same year it was $70.67 \mathrm{ha}$. Despite the fact that the $90 \%$ KHR for the autumn of 2015 had data for only 2.5 months, this became the third largest home range size (55.20 ha).

As for sow2, the total 90\% KHR was 9.2 ha (Table 4). The summer home range size was fairly close to the total one with 7.46 ha. In spring, we detected 12.73 ha. The largest home range size was recorded in winter, 32.18 ha. The size of sow $1_{\text {sh }}$ 's total $90 \%$ KHR was 26.93 ha (Table 5). The summer home range size ( $29.22 \mathrm{ha}$ ) is similar in size to the total. The largest home range size was detected in winter (45.45 ha). The smallest home range size was recorded in autumn (17.37 ha).

For both sows, the largest 90\% KHR was detected in winter, but the second sow's KHR is about half the size as that of sow1's (70.67 ha and 32.18 ha, respectively). The smallest home range size was recorded in spring for sow1 (20.32 ha), and in summer for the second one (7.46 ha), if we ignore the 1 month in autumn.

Comparing the $90 \%$ KHR sizes of sow $1_{\mathrm{sh}}$ and sow2, large deviation could be observed. The only matching results were gained for the winter of sow 2 and the summer of sow $1_{\text {sh }}$, which were similar in size (32.18 ha and 29.22 ha, respectively).

As for the $60 \%$ KHR sizes, the total one for sow 1 was 6.10 ha (Table 3; Fig. 4). This is just slightly larger than what we recorded in spring (4.69 ha) and in summer (4.23 ha). The largest $60 \%$ KHR was detected in winter (17.94 ha), while the second largest in the autumn of 2014 (12.73 ha). The third largest $60 \%$ KHR was recorded in autumn of 2015 with 8.30 ha. In the case of sow2, the total $60 \%$ KHR was 2.41 ha (Table 4). The largest $60 \%$ KHR was detected in spring (4.58 ha), while the smallest was recorded in summer (1.46 ha).

The total $60 \%$ KHR size of sow 2 is about third the size of the first sow (6.10 ha and 2.41 ha respectively), while the smallest ones were recorded in summer also for both marked animals (4.23 ha and 1.46 ha), if we do not take into account the autumn month in the case of sow2. The largest $60 \%$ KHR was detected in winter for sow1 (17.94 ha) and in spring for the second one (4.58 ha). The home ranges of spring and summer of sow 1 (4.69 ha and 4.23 ha, respectively) are almost the same size as sow2's winter and spring home ranges (4.27 and 4.58 ha, respectively).

As for sow $1_{\text {sh }}$, the total $60 \%$ KHR was 4.55 ha (Table 5). The summer and spring home range sizes were fairly close to the total one with 4.23 ha and 4.69 ha. In autumn, we detected 3.15 ha. The largest home range size was recorded in winter, 9.14 ha. Comparing the $60 \%$ KHR sizes of sow $1_{\text {sh }}$ and sow2, large deviation could be also observed. 


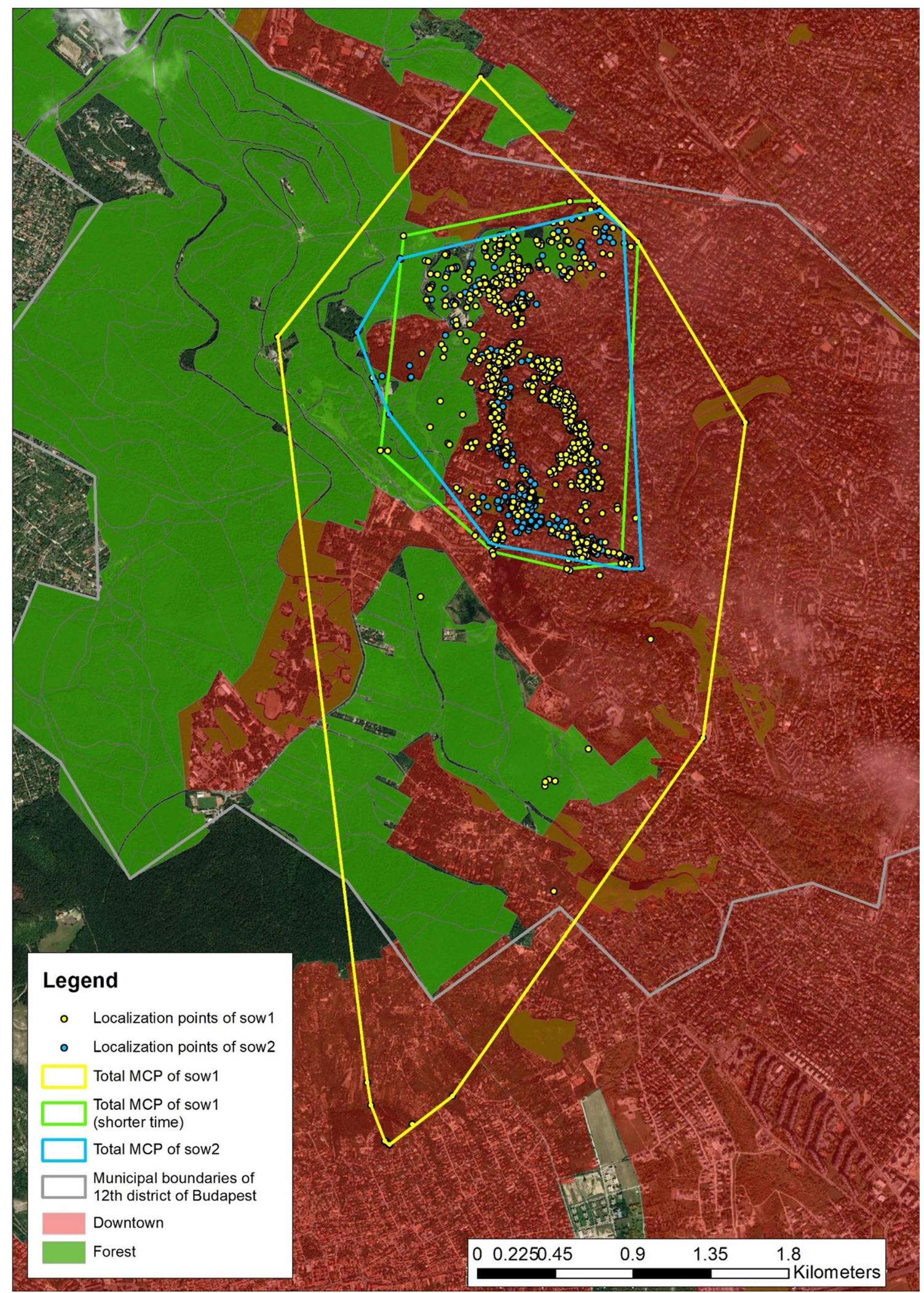

Fig. 2 Total minimum convex polygon of sow1, sow1 (shorter time) and sow2 
Table 3 Seasonal and total minimum convex polygon and kernel home range sizes of sow1

\begin{tabular}{lllllll}
\hline Size (ha) & Autumn 2014 & Winter & Spring & Summer & Autumn 2015 & Total \\
\hline MCP & 729 & 222 & 162 & 148 & 404 & 1040 \\
$90 \%$ KHR & 70.65 & 70.67 & 20.32 & 29.22 & 55.20 & 37.20 \\
$60 \%$ KHR & 12.73 & 17.94 & 4.69 & 4.23 & 8.30 & 6.10 \\
\hline
\end{tabular}

Table 4 Seasonal and total minimum convex polygon and kernel home range sizes of sow2

\begin{tabular}{llllll}
\hline Size (ha) & Autumn & Winter & Spring & Summer & Total \\
\hline MCP & 0.14 & 121 & 227 & 35 & 244 \\
$90 \%$ KHR & 0.03 & 32.18 & 12.73 & 7.46 & 9.2 \\
$60 \%$ KHR & 0.006 & 4.27 & 4.58 & 1.46 & 2.41 \\
\hline
\end{tabular}

Table 5 Seasonal and total minimum convex polygon and kernel home range sizes of sow 1 in shorter time (265 days)

\begin{tabular}{llllll}
\hline Size (ha) & Autumn & Winter & Spring & Summer & Total \\
\hline MCP & 147 & 154 & 162 & 148 & 256 \\
$90 \%$ KHR & 17.37 & 45.45 & 20.32 & 29.22 & 26.93 \\
$60 \%$ KHR & 3.15 & 9.14 & 4.69 & 4.23 & 4.55 \\
\hline
\end{tabular}

The only matching results were gained for the spring and winter of sow 2 and the spring and summer of sow $1_{\text {sh }}$, which were similar in size (4.58 ha, 4.27 ha, 4.69 ha and 4.23 ha, respectively). The home range size in spring was similar in size in both cases ( 4.69 ha and 4.58 ha, respectively).

\section{Discussion}

Considering the size and the characteristics of the 12th district of Budapest, the two marked sows were predominantly using the urban areas, particularly the inner city areas. Although $42.74 \%$ of this district is continuous forest, the sows were only present in those parts in $23.20 \%, 21.33 \%$ and $13.19 \%$ of the cases, respectively. This tendency could also be observed when examining the seasons. These results indicate that our first hypothesis was correct. Based on the localisation points, neither of the sows left the area of Budapest.

However, we partly rejected our second hypothesis, which presumed that within the populated areas these animals preferred those parts outside the city which have rich in potential hiding places and less human disturbance. It is true that in most cases they used richly covered areas with dense vegetation, but human disturbance was also high in those parts. It is fairly difficult to decide whether a certain home range size in an urban environment is small, normal or large. In order to determine this, we needed to compare our results with those of other studies.

As a reference, we used the chart of Keuling et al. (2008b), where extremely varied and diverse home ranges are shown. The reason for this is the time of research, geographical differences and the number of studied individuals. The study was carried out in lowlands habitat of North Germany, and they compared their results to the home range sizes given in the literature for female wild boar in Europe and USA (various habitat types). For having more accurate results, we only used those home range types for comparison which we had in our research (annual/total and seasonal home range sizes) and which were also clearly found in the work of Keuling et al. In addition, we used several other sources of reference in order to determine whether our results of home range sizes can be regarded as small or large.

Comparison of the home range sizes given by minimum convex polygon does not provide a clear answer. This is because the MCP method, due to its way of calculation, overestimates home range sizes. When examining the annual (total) MCP sizes, our results of 1040 ha, 256 ha and 244 ha show a varied picture compared to the data found in other sources. The annual MCP in the work of Keuling et al. (2008b) was between 770 and 1295 ha. In the research of Jánoska et al. (2018), they estimated home ranges in two Romanian habitats (in a lowland and a mountains area), where the annual MCP was between 1060 and 12,001 ha, whereas it is 455 ha in the paper of Massei et al. (1997). Annual MCP's was reported by Boitani et al. (1994): 370 ha, 560 ha and 2400 ha. Keuling et al. (2008b) refer to Baubet's 1998 paper, where MCP's of 760 ha, 940 ha, 960 ha and 1380 ha are reported. Tari et al. (2014) reported $4498 \pm 1434$ ha home range in lowland, whereas Tari et al. (2017) published 1215 ha (around Balatonfüred), 869 $\pm 93,3$ ha (around Örvényes) and 209 ha (around Szántód).

As far as seasonal MCP sizes are concerned, we only found data for summer and winter seasons. Our three summer MCP sizes of 148 ha (in cases of sow 1 and sow $1_{\text {sh }}$ ) and 35 ha are the smallest sizes of all the data we found in other sources. The smallest summer MCP was 345 ha in the study of Singer et al. (1981). Other published summer MCP's are: 1100 ha (Keuling et al. (2008b) referring to Baubet's paper of 1998), 1225 ha (Keuling et al. (2008b) referring to Baubet et al. 1998) and 1395 ha (Maillard and Fournier 1995). Our winter home ranges were 222 ha, 154 ha and 121 ha. 


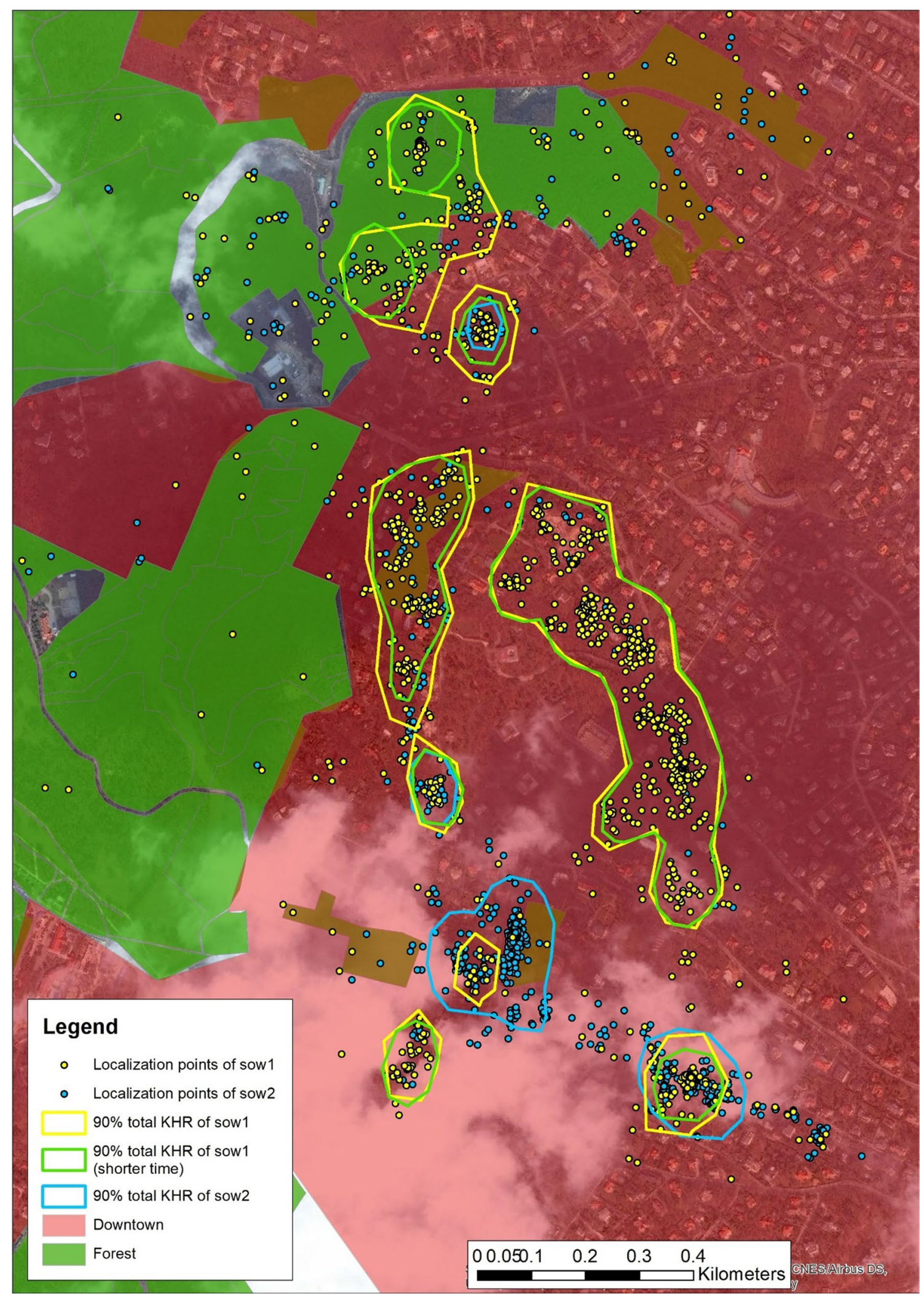

Fig. 3 Total 90\% kernel home range of sow1, sow1 (shorter time) and sow2 


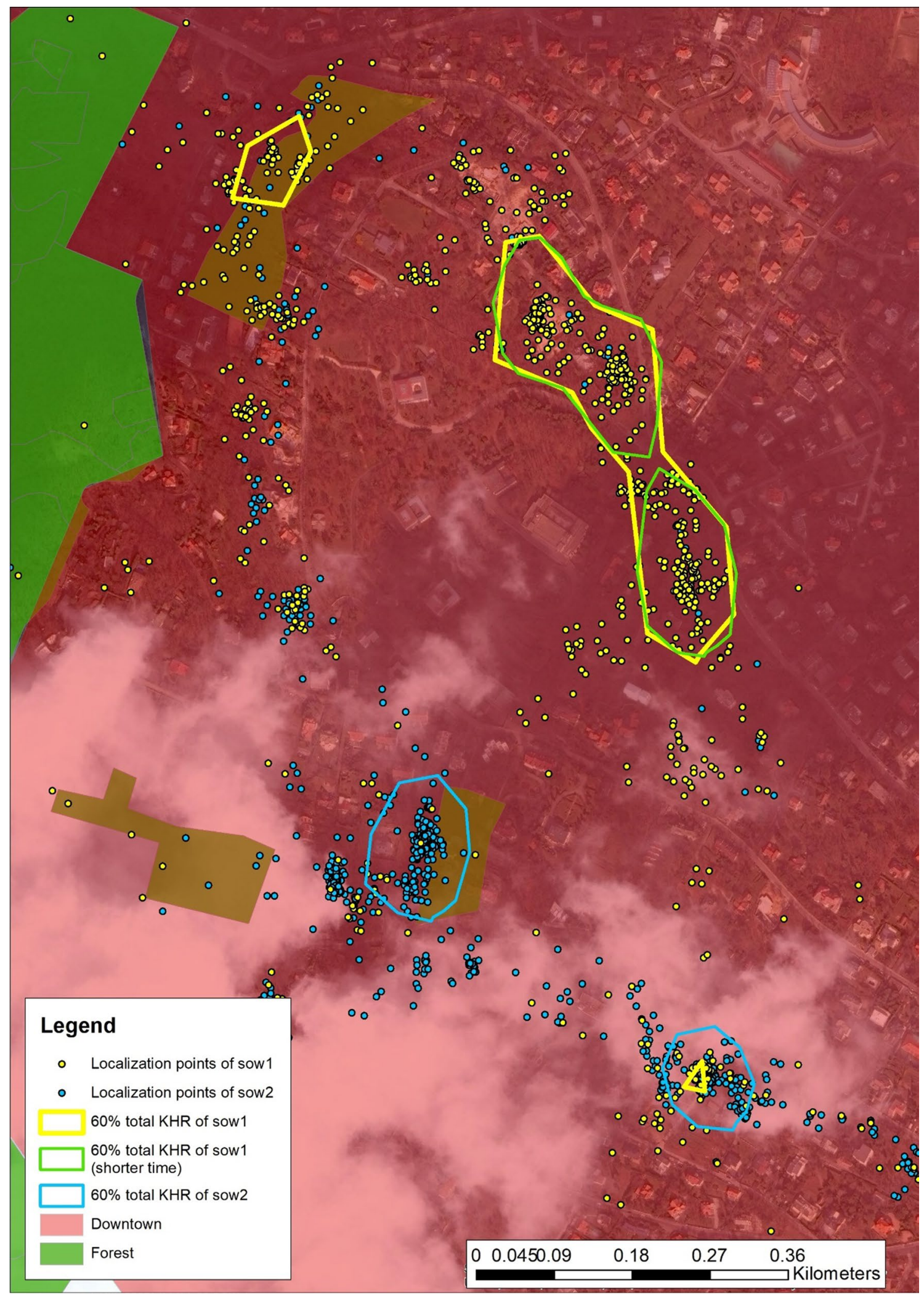

Fig. 4 Total 60\% kernel home range of sow1, sow1 (shorter time) and sow2 
Singer et al. (1981) reported 265 ha and 1395 ha (Singer et al. 1981), whereas Baubet et al. (1998) published 415 ha.

More accurate home range sizes can be defined by using the kernel home range method. Our total KHR results are far smaller than those published by Keuling. Although in the chart of Keuling et al. (2008b) it is not indicated whether they used $90 \%$ KHR or $60 \%$ KHR sizes, it is irrelevant to the results. Even if we consider the larger KHR sizes $(90 \%$ $\mathrm{KHR}$ ), it is clear that our results (KHR sow $1=37.20$ ha, KHR sow $1_{\text {sh }}=26.93$ ha, KHR sow $2=9.2$ ha) are remarkably smaller than the ones reported by Keuling et al. (2008b), which are 400 ha and 600 ha. Jánoska et al. (2018) published $90 \%$ KHR results. The $90 \%$ KHR sizes of the individuals they studied ranged between 115 and 1410 ha. Calenge et al. (2002) reported 380 ha and 530 ha summer KHR sizes. Tari et al. (2017) reported 90\% KHR (on the three study areas) between 17,7 ha and 109 ha, whereas $60 \%$ KHR were between 4,25 ha and 26,5 ha.

When comparing our results to those published in other sources, it is clear that the home range sizes of the two sows we examined are noticeably smaller both by the minimum convex polygon and the kernel home range methods. Thus, our third hypothesis, presuming that the home ranges of the wild boars living in urban areas are smaller than those of the wild boars living in their natural environment, proved to be true. The extremely small home range sizes shown by the MCP, but especially the KHR methods, can be explained by the characteristics of the 12 th district. This is predominantly a suburban, green area, with plenty of abandoned gardens, orchards and forests, which provide not only an abundance of food resources, but also lots of suitable hiding places for the animals (Bogdán and Heltai 2014; Deutsch and Heltai 2017). As Abaigar et al. (1994) pointed out: if the wild boar can find both food and shelter in the dense vegetation, it will certainly use and prefer that habitat. The abandoned, and therefore neglected, uncared for and thus animal-friendly gardens make this area extremely rich in food and hiding places (Bogdán and Heltai 2014; Deutsch and Heltai 2017). In the study area, the wild boar sows could find everything they need (food and shelter) in one place; therefore, there was no pressure and need to use a larger home range. This is also supported by other scientific studies which concluded that the home range of a wild boar was smaller if food was available in large quantities (Singer et al. 1981; Boitani et al. 1994; Massei et al. 1997), and in addition, suitable hiding places were provided (Fischer et al. 2004).

\section{Conclusion for future biology}

A city habitat management could be the best solution to prevent an animal from being attracted to the urban environment. Habitat modification, e.g. clearing undergrowth vegetation, could result that wild boars cannot find any hiding places. The significant part of food sources will disappear with the elimination of these places. By eliminating the two main factors together could prevent wild boars finding their living conditions within the city. It is interesting for the future management of urban wild boars that African Swine Fever (ASP) appeared recently in the immediate vicinity of Budapest. Its spread could affect not only wild boars in natural habitat but also individuals living in the city.

Involving the public is essential to find and implement an effective solution. The inhabitants must be informed in various forms and in different ways. An information booklet or a website could be effective. The brochure or website must be comprehensive. A description shall be provided of what may cause the appearance of a wild animal in urban areas (e.g. easy access to food, appropriate hiding places, etc.). What are the dangers of appearance (e.g. damage to human property, human-animal conflicts, possibility of attack, appearance of various diseases, etc.)? The prospectus should explain what each individual can do to avoid conflicts, who can be notified when they observe a wild animal at their place of residence, and the opportunity to contact the institution or organisation for further questions. In addition, legislative changes would be needed to facilitate, within a strictly regulated framework, the action of professional hunters or designated organisations/persons within the populated area.

The problems caused by wild animals appearing in the city can be solved only in a complex way. Involvement of the persons concerned and cooperation of organisations and agencies is required. However, the most important thing is the prevention. It is necessary to search for potential habitats, to identify possible sources of food and, if possible, to eliminate the source of food or to exclude it from the wildlife (e.g. through efficient, suitable fences). Applying the appropriate methods and well-thought-out strategy, the problem at hand could be addressed.

Acknowledgements Open access funding provided by Szent István University (SZIE). We are grateful to Ministry of Agriculture and Pilis Park Forestry Company helping us in the field data collections. We are grateful to our late colleague, Attila Beregi (1962-2018), who performed the anaesthesia of marked wild boars. Rest in peace!

Authors' contribution Adrienn Csókás contributed to processing telemetry data, evaluation and analysis of data and writing paper; Miklós Heltai is the leader of the project funded by the Ministry, in which the actual research was also performed, research planning; Gergely Schally contributed to processing telemetry data and data analysis; László Szabó conducted field work and data analysis; Sándor Csányi evaluated and analysed data; Ferenc Kovács conducted field work.

Funding The publication is supported by the EFOP-3.6.3VEKOP-16-2017-00008 project. The project is co-financed by the 
European Union and the European Social Fund. The data collection was supported by the Pilis Park Forestry and the Ministry of Agriculture.

Data availability Data can be available directly from the authors upon request on an individual basis.

\section{Compliance with ethical standards}

Conflict of interest Authors make a statement that they have no competing interests.

Ethical statement No ethical issues were raised during the investigation. The investigations did not cause any damage or significant disturbance to any living organism, animal or plant individual studied.

Open Access This article is licensed under a Creative Commons Attribution 4.0 International License, which permits use, sharing, adaptation, distribution and reproduction in any medium or format, as long as you give appropriate credit to the original author(s) and the source, provide a link to the Creative Commons licence, and indicate if changes were made. The images or other third party material in this article are included in the article's Creative Commons licence, unless indicated otherwise in a credit line to the material. If material is not included in the article's Creative Commons licence and your intended use is not permitted by statutory regulation or exceeds the permitted use, you will need to obtain permission directly from the copyright holder. To view a copy of this licence, visit http://creativecommons.org/licenses/by/4.0/.

\section{References}

Abaigar T, Del Barrio G, Vericad JR (1994) Habitat preference of wild boar (Sus scrofa L., 1758) in a Mediterranean environment. Indirect evaluation by signs. Mammalia 58:201-210

Acevedo PE, Escuredo MA, Muńoz R, Gortázar C (2006) Factors affecting wild boar abundance across an environmental gradient in Spain. Acta Ther 50:327-336

Badry M, Hesse G (2010) British Columbia urban ungulate conflict analysis. British Columbia Ministry of Environment

Bogdán O, Heltai M (2014) A vaddisznó előfordulásának vizsgálata Budapesten. Vadbiológia 16:87-96

Boitani L, Mattei L, Nonis D, Corsi F (1994) Spatial and activity patterns of wild boars in Tuscany, Italy. J Mamm 75:600-612

Brash AR, Brower EVP, Henrey L, Savageau D (2004) Report on managing Greenwich's deer population. Greenwich Conservation Commission Wildlife Issues Committee

Cahill S, Llimona F (2004) Demographics of a wild boar (Sus scrofa, Linnaeus, 1758) population in a metropolitan park in Barcelona. Galemys 16:37-52

Cahill S, Llimona F, Grácia J (2003) Spacing and nocturnal activity of wild boar (Sus scrofa) in a Mediterranean metropolitan park. Wildl Biol 9:3-13

Cahill S, Llimona F, Cabaneros L, Calomardo F (2012) Characteristics of wild boar (Sus scrofa) habituation to urban areas in the Collserola Natural Park (Barcelona) and comparison with other locations. Anim Biodiv Cons 35:221-233

Calegne C, Maillard D, Fournier P, Fouque C (2004) Efficiency of spreading maize in the garrigues to reduce wild boar (Susscrofa) damage to Mediterranean vineyards. Eur J Wildl Res 50:112-120

Calenge C, Maillard D, Vassant J, Brandt S (2002) Summer and hunting season home ranges of wild boar (Sus scrofa) in two habitats in France. Game Wildl Sci 19:281-301
Creacy G (2006) Deer management within suburban areas. Texas Parks and Wildlife

Cuevas MF, Novillo A, Campos C, Dacar MA, Ojeda RA (2010) Food habits and impact of rooting behaviour of the invasive wild boar, Sus scrofa, in a protected area of the Monte Desert, Argentina. Jrid Environ 74:1582-1585

Deutsch F, Heltai M (2017) A vaddisznó jelenlétének vizsgálata közvetett jelek alapján egyes budai kerületekben. Vadbiológia 19:1-12

Ditchkoff SS, Saalfeld S, Gibson CJ (2006) Animal behavior in urban ecosystem: modifications due to human-induced stress. UrbEcosys 9:5-12

Fischer C, Gourdin H, Obermann M (2004) Spatial behaviour of the wild boar in Geneva, Switzerland: testing methods and first results. Galemys 16:149-155

Gehrt SD (2007) Ecology of coyotes in urban landscapes. In: Nolte DL, Arjo WM, Stalman DH (eds) Proceedings of the 12th wildlife damage management conference

Gemson G, Johnson AS, Kenward R, Ripley R, MacDonald D (2005) Are kernels the mustard? Data from global positioning system (GPS) collars suggests problems for kernel home-range analyses with least-square cross-validation. J Anim Ecol 74:455-463

Hamrick B, Smith M, Jaworowski C, Strickland B (2011) A landowner's guide for wild pig management: practical methods for wild pig control. Mississippi State University Extension Service \& Alabama Cooperative Extension System

Harris S (1984) Ecology of urban badgers (Meles meles): distribution in Britain and habitat selection, persecution, food and damage in the city of Bristol. Biol Conserv 28:349-375

Hegglin D, Bontadina F, Gloor SA, Seild JR, Müller U, Breitenmoser U, Deplazes P (2004) Baiting red foxes in an urban area: a camera trap study. J Wildl Manag 68:1010-1017

Heltai M, Szốcs E (2008) Városi vadgazdálkodás. Jegyzet vadgazda mérnöki szakos hallgatók részére. Szent István Egyetem, Gödöllő

Heltai M, Kovács F, Rácz K, Csépányi P, Nagy A (2016) A vaddisznó táplálkozásának vizsgálata lakott környezetben, Budapesten. Vadbiológia 18:27-34

Jánoska F, Farkas A, Marosán M, Fodor JT (2018) Wild boar (Sus scrofa) home range and habitat use in two Romanian habitats. Acta Silv\&Lign Hung 14:51-63

Katona K, Heltai M (2018) A vaddisznó táplálék-összetételének és táplálkozási sajátságainak szakirodalmi áttekintése. Tájökol Lapok 16:65-74. Retrieved from http://real.mtak.hu/82529/1/07_Katon a_Heltai_u.pdf

Katona K, Lakatos EA, Márton M, Szabó L, Csókás A, Csányi S (2018a) A vaddisznó budapesti jelenlétének lehetséges táplálkozási okai. Czikkelyné ÁN, Sándor K, Seress G (szerk.) 1. Urbanizációs Ökológia Konferencia Veszprém. Pannon Egyetem, Magyarország, p 44

Katona K, Lakatos EA, Márton M, Szabó L, Csókás A, Csányi S (2018b) Feeding habits of urban wild boar in Budapest, Hungary. Modern aspects of sustainable management of game populations. In: 6th international wildlife and game management symposium: book of abstracts, $\mathrm{p} 17$

Keuling O, Stier N, Roth M (2008a) How does hunting influence activity and spatial usage in wild boar Sus scrofa L.? Eur J Wildl Res 54:729-737

Keuling O, Stier N, Roth M (2008b) Annual and seasonal space use of different age classes of female wild boar Sus scrofa L. Eur J Wildl Res 54:403-412

Kotulski Y, König A (2008) Conflicts, crises and challenges: wild boar in the Berlin city-a social empirical and statistical survey. NatCroatica 17:233-246

Licoppe A, Prévot C, Heymans M, Bovy C, Caesar J, Cahill S (2013) Managing wild boar in human-dominated landscape. In: International union of game biologist-congress IUGB 2013, Brussles, Belgium 
Maillard D, Fournier P (1995) Effect of shooting with hounds on home range size of Wild Boar (Sus scrofa L.) groups in Mediterranean habitat. IBEX JME 3:102-107

Massei G, Genov PV, Staines BW, Gorman ML (1997) Factors influencing home range and activity of wild boar (Sus scrofa) in a Mediterranean coastal area. J Zool 242:411-423

Massei G, Roy S, Bunting R (2011) Too many hogs? A review of methods to mitigate impact by wild boar and feral hogs. Hum Wildl Int 5:79-99

McGaw CC, Mitchell J (1998) Feral pigs (Sus scrofa) in Queensland. Pest status review series-land protection. The Department of Natural Resources and Mines, Queensland

Mohr CO (1947) Table of equivalent populations of North American small mammals. Am Midland Nat 37:223-249

Møller AP (2009) Successful city dwellers: a comparative study of the ecological characteristics of urban birds in the Western Palearctic. Oecologia 159:849-858

Møller AP, Diaz M, Flensted-Jensen E, Grim T, Ibánez-Álamo JD, Jokimaki J, Mand R, Markó G, Tryjanowski P (2012) High urban population density of birds reflects their timing of urbanization. Oecologia 170:867-875

Prange S, Gehrt SD, Wiggers EP (2003) Demographic factors contributing to high raccoon densities in urban landscape. J Wildl Manag 67:324-333

Singer FJ, Otto DK, Tipton AR, Hable CP (1981) Home ranges, movements, and habitat use of European Wild Boar in Tennessee. $\mathrm{J}$ Wildl Manag 45:343-353
Sütő D, Heltai M, Katona K (2020) Quality and use of habitat patches by wild boar along an urban gradient. Biol Futura (in press)

Tari T, Sándor Gy, Heffenträger G, Pócza G, Náhlik A (2014) A vaddisznó területhasználata és aktivitása egy síkvidéki élőhelyen. Lipák L (szerk.) Alföldi Erdőkért Egyesület Kutatói Nap XXII: Tudományos eredmények a gyakorlatban. Alföldi Erdőkért Egyesület, Kecskemét, pp 29-36

Tari T, Sándor Gy, Heffenträger G, Náhlik A (2017) A vaddisznó előfordulása és viselkedésének jellemzői Balaton-parti településeken. In: Blanka V, Ladányi Z (eds) Interdiszciplináris tájkutatás a XXI. században: a VII. Magyar Tájökológiai Konferencia tanulmányai Szeged, Magyarország: Szegedi Tudományegyetem Földrajzi és Földtudományi Intézet, pp 597-604

Taylor RB (1999) Seasonal diets and food habits of feral swine. In: Feral-swine conference, pp 58-66

Thurfjell H, Spong G, Olsson M, Ericsson G (2015) Avoidance of high traffic levels result in lower risk of wild boar-vehicle accidents. Landsc Urban Plan 133:98-104

Weckel M, Rockwell RF (2013) Can controlled bow hunts reduce overabundant white-tailed deer populations in suburban ecosystem? Eco Model 250:143-154

West BC, Cooper AL, Armstrong JB (2009) Managing wild pigs: a technical guide. Hum Wildl Interact Monogr 1:1-55

Worton BJ (1989) Kernel methods for estimating the utilization distribution in home-range studies. Ecology 70:164-168 